\title{
EVALUASI STABILITAS FARMASETIK DAN UJI IRITASI FORMULA MASKER SARI LEMON (Citrus limon L.) DENGAN YOGURT PLAIN
}

\author{
Iskandar Zulkarnain', Ermina Pakki ${ }^{2}$, Mirawati ${ }^{1}$, Arin Rizki Talib \\ ${ }^{1}$ Fakultas Farmasi Universitas Muslim Indonesia, Makassar \\ ${ }^{2}$ Fakultas Farmasi Universitas Hasanuddin, Makassar \\ Email: iskandar.zulkarnain@umi.ac.id
}

\begin{abstract}
The use of lemon juice and yogurt can provide good care for facial skin, so have the potential to be formulated into a mask to overcome skin problems. The study aimed to produce a mask dosage froms formula pharmaceutically stable and not irritating. The lemon juice extract was obtained by using freeze-drying, and optimization of anionic emulgator (TEA-Stearate) and nonionic emulgator (Tween-Span 60) are carried out. The formulation was continued with the variations in lemon extract concentrations of $0.5 ; 1$; and $2 \% w / v$ by evaluating the physical characteristics and stability with parameters including organoleptic examination (smell, color, and consistency), centrifugation, homogeneity, $\mathrm{pH}$, type of emulsion, drying time, dispersion, viscosity, and determination of flow type before and after conditions are forced at $5^{\circ} \mathrm{C}$ and $35^{\circ} \mathrm{C}$ for the 10 cycles for irritation testing using test rabbits. The results showed that the formula with an anionic emulgator (TEA-stearic) of 1:2\% b/v with a lemon extract concentration of $1 \%$ was a pharmaceutically stable formula and the irritation the results showed that the formula with a lemon extract of $0.5 \%$ and $1 \%$ $b / v$ did not cause any irritation.
\end{abstract}

Key words: Lemon juice, Citrus limon L., yought plain, cream mask, irritation.

\section{PENDAHULUAN}

Jeruk lemon (Citrus limon (L.)

Burm. f.) merupakan bahan alam yang berpotensial sebagai bahan kosmetik karena berkhasiat sebagai antioksidan, mencegah penuaan dini, dan mencerahkan wajah. Sari lemon mengandung asam sitrat dan kaya akan vitamin C. Asam sitrat bekerja sebagai exfoliate (meluruhkan sel kulit mati) pada kulit, juga memiliki sifat astringent sehingga dapat mengeringkan noda jerawat. Sari lemon bertindak sebagai antiaging karena memiliki antioksidan yang dapat menghilangkan kerutan dan komedo. Sari lemon juga merupakan skin lightener alami yang dapat mengurangi kemerahan pada jerawat, mempercepat proses penyembuhan dan mencerahkan kulit. ${ }^{1}$

Yoghurt merupakan hasil fermentasi susu dengan bakteri asam 
Evaluasi stabilitas farmasetik dan uji iritasi formula masker sari lemon (Citrus limon L.) dengan yogurt plain

laktat Lactobacillus bulgaricus dan Streptococcus thermophillus. ${ }^{2}$ Yogurt adalah sumber kalsium, vitamin $\mathrm{D}$, dan protein yang sangat baik untuk kulit.Yogurt mengandung asam laktat dan alpha hydroxy acid yang dimana dapat membantu melembabkan dan exfoliating(meluruhkan sel kulit mati) pada kulit sehingga membuat kulit tampak halus dan cerah serta membantu mencegah jerawat, dan membantu memperbaiki perubahan warna kulit pada age spots (bintik-bintik penuaan). ${ }^{3}$ Yoghurt juga bermanfaat untuk megencangkan dan menyejukan kulit. ${ }^{4}$

Berdasarkan hal tersebut, kombinasi sari lemon dan yoghurt menjanjikan perawatan yang optimal pada kulit wajah, sehingga pada penelitian ini kedua bahan tersebut diformulasikan menjadi kosmetik dalam bentuk sediaan krim masker.

Masker memiliki beberapa bentuk sediaan, salah satunya adalah krim. ${ }^{5}$ Krim masker merupakan salah satu sediaan kosmetik yang diberikan secara topikal, terutama pada wajah. ${ }^{6}$ Krim masker merupakan emulsi yang dibuat dengan tipe minyak dalam air sehingga dapat dicuci dengan air agar memberikan kenyamanan dan estetika yang baik. Selain itu, krim masker harus memiliki kestabilan yang baik pada saat penggunaan dan penyimpanan, salah satu faktor yang mempengaruhi kestabilan yaitu pemilihan emulgator yang tepat dalam formulasi. Emulgator adalah bahan penstabil emulsi yang membentuk lapisan yang mengelilingi tetesan terdispersi sehingga mencegah koelesensi dan terpisahnya fase terdispersi.

\section{METODE PENELITIAN}

\section{Alat dan Bahan}

Alat yang digunakan pada penelitian diantaranya freeze drying (IKA®), hot plate stirrer (IKA®), pH meter, timbangan analitik (Ohaus $\AA$ ), thermometer (EUTECH), ultaturax, dan viskometer (Brookfield®DVI-Prime). Bahan yang digunakan antara lain, asam stearat, aquadest, HPMC, metilparaben, Na.EDTA, parafin cair, propilenglikol, propilparaben, sari jeruk lemon (Citrus limon L.), span 60, setostearil alcohol, trietanolamin, tween 60 , yogurt plain,dan zink oxid.

\section{Prosedur Kerja \\ Penyiapan sampel}

Jeruk lemon dipotong menjadi 2 bagian kemudian diperas dan diambil sarinya. Hasil perasan buah jeruk lemon kemudian di freeze drying pada suhu -100C sampai -400C untuk mendapatkan ekstrak kental dan selanjutnya ditimbang. 
Evaluasi stabilitas farmasetik dan uji iritasi formula masker sari lemon (Citrus limon L.) dengan yogurt plain

\section{Optimasi emulgator TEA-Stearat}

Semua bahan ditimbang sesuai dengan perhitungan. Komponen fase minyak dibuat dengan meleburkan terlebih dahulu asam stearat, setostearil alcohol dan propilparaben kemudian dimasukkan paraffin cair sambil terus diaduk hingga homogeny diatas penangas air. Fase air dibuat dengan mencampurkan dispersi HPMC, TEA, propilenglikol, metilparaben, natrium EDTAdan air lalu diaduk hingga homogen. Setelah homogeny panaskan masing-masing fase pada suhu $70^{\circ} \mathrm{C}$. Emulsi dibuat dengan memasukkan fase minyak kedalam fase air sedikit demi sedikit kemudian diaduk dengan menggunakan ultraturax dengan kecepatan 15.000 rpm selama 15 menit hingga terbentuk emulsi. Sambil dilakukan pengadukan ekstrak lemon, zink oksid dan yogurt dicampur kemudian didispersikan merata kedalam emulsi yang telah terbentuk. ${ }^{7}$ Sediaan emulsi yang dihasilkan disentrifugasi dengan kecepatan 3750 rpm selama 5 jam. ${ }^{8}$

Optimasi emulgator tween 60 dan span 60

Semua bahan ditimbang sesuai dengan perhitungan. Komponen fase minyak dibuat dengan meleburkan paraffin cair, propilparaben, setostearil alkohol, asam stearat dan span 60 di atas penangas air sambil diaduk. Fase air dibuat dengan mencampurkan dispersi HPMC, tween 60, propilenglikol, metilparaben, natrium EDTA dan air lalu diaduk hingga homogen. Setelah homogen panaskan masing-masing fase pada suhu $70^{\circ} \mathrm{C}$. Emulsi dibuat dengan memasukkan fase minyak kedalam fase air sedikit demi sedikit kemudian diaduk dengan menggunakan ultraturax dengan kecepatan 15.000 rpm selama 15 menit hingga terbentuk emulsi. Sambil dilakukan pengadukan, ekstrak sari lemon, zinc oxid, dan yogurt dicampur kemudian didispersikan merata kedalam emulsi yang telah terbentuk. ${ }^{7}$ Setelah pembuatan emulsi selesai, sediaan dimasukkan kedalam tabung sentrifug dan disentrifugasi dengan kecepatan 3750 rpm selama 5 jam. ${ }^{8}$

Pengujian Karakteristik Fisik dan Stabilitas Sediaan

Evaluasi kestabilan masker dilakukan dengan kondisidi paksakan (Stressed condition) dengan penyimpanan pada suhu penyimpanan 50C dan 350C secara bergantian masing-masing 12 jam selama 10 siklus. Parameter yang diukur adalah organoleptis, $\mathrm{pH}, \quad$ viskositas, homogenitas waktu sediaan 
Evaluasi stabilitas farmasetik dan uji iritasi formula masker sari lemon (Citrus limon L.) dengan yogurt plain

mengering, tipe emulsi, daya sebar, tipe aliran.

\section{Uji iritasi}

Pengujian iritasi dilakukan pada 3 ekor kelinci dewasa albino, sehat, dan bobot badan 1,5-2 kg, dengan bagian belakang yang dicukur bulu punggungnya, 1 inchi persegi dengan 6 pola. Sediaan sebanyak $0,5 \mathrm{~g}$

\section{HASIL PENELITIAN}

Tabel 1. Hasil pengujian $\mathrm{pH}$ sediaan masker sari lemon (Citrus limonL.) dan yogurt plain sebelum dan sesudah kondisi dipaksakan

\begin{tabular}{ccc}
\hline Formula & \multicolumn{1}{c}{} & \\
\cline { 2 - 3 } & Sebelum & Sesudah \\
\hline 1 & $7 \pm 0$ & $7 \pm 0$ \\
3 & $5,6 \pm 0,6$ & $6 \pm 0$ \\
\end{tabular}

Tabel 2. Hasil pengujian waktu mengering sediaan masker dari sari lemon (Citrus limon L.) dan yogurt plain

\begin{tabular}{cc}
\hline Formula & Waktu Mengering (menit) \\
\hline 1 & 16,95 \\
2 & 19,59 \\
3 & 17,83 \\
\hline
\end{tabular}

Tabel 3. Hasil pengujian daya sebar sediaan masker sari lemon (Citrus limon L.) dan yogurt plain

\begin{tabular}{ccccc}
\hline \multirow{3}{*}{ Formula } & \multicolumn{4}{c}{ Daya sebar rata-rata (cm) } \\
\cline { 2 - 5 } & $\mathbf{5}$ & $\mathbf{5 0}$ & $\mathbf{1 0 0}$ & $\mathbf{1 5 0}$ \\
\cline { 2 - 5 } & 6,06 & 6,66 & 7,41 & 7,98 \\
2 & 6,85 & 7,61 & 8,16 & 8,61 \\
3 & 6,1 & 6,61 & 7,21 & 7,63 \\
\hline
\end{tabular}


Evaluasi stabilitas farmasetik dan uji iritasi formula masker sari lemon (Citrus limon L.) dengan yogurt plain

Tabel 4. Hasil pengamatan uji organoleptis masker dari sari lemon (Citrus limon L.) dan yogurt plain sebelum dan sesudah kondisidi paksakan

\begin{tabular}{ccccc}
\hline \multirow{2}{*}{ Formula } & \multirow{2}{*}{ Kondisi } & \multicolumn{3}{c}{ JenisPemeriksaan } \\
\cline { 4 - 5 } & Sebelum & Bau & Warna & Konsistensi \\
\hline \multirow{2}{*}{1} & Sesudah & Khas & Putih & Kental \\
\hline \multirow{2}{*}{2} & Sebelum & Khas & Putih & Kental \\
\hline \multirow{2}{*}{3} & Sesudah & Khas & Putih & Kental \\
\hline & Sebelum & Khas & Putih & Kental \\
\hline & Sesudah & Khas & Putih & Kental \\
\hline
\end{tabular}

Tabel 5. Hasil pengujian viskositas sediaan masker sari lemon (Citrus limon L.) dan yogurt plain sebelum dan sesudah dikondisi dipaksakan

\begin{tabular}{cccc}
\hline \multirow{2}{*}{ Kondisi } & \multicolumn{3}{c}{ Rata-Rata viskositas (P) } \\
\cline { 2 - 4 } & Formula 1 & Formula 2 & Formula 3 \\
Sebelum & $68,03 \pm 8,64$ & $39,767 \pm 7,76$ & $63,9 \pm 3,41$ \\
Sesudah & $48,867 \pm 6,70$ & $40,267 \pm 15,60$ & $57,9 \pm 24,83$ \\
\hline
\end{tabular}

\section{PEMBAHASAN}

Kombinasi lemon dan yogurt adalah bahan utama pada penelitian ini, keduanya memberikan efek perawatan pada kulit. Pada penelitian ini dibuat sediaan masker dari sari lemon dan yogurt dengan memformulasikan menggunakan emulgator anionik (TEA-stearat) dan emulgator nonionic (Tween dan span 60). Emulgator merupakan bahan utama pembentuk emulsi dan juga menstabilkan emulsi oleh karena itu pemilihan bahan emulgator yang sesuai merupakan faktor yang penting untuk diperhatikan dalam sediaan berbasis emulsi untuk menghasilkan sediaan yang baik.

Ekstrak sari lemon diperoleh dengan cara liofilisasi menggunakan freeze dryer. Hasil ekstraksi yang diperoleh dari $151 \mathrm{~g}$ lemon segar sebesar 0,99 g ekstrak kental, sehingga \% rendamen yang didapatkan ialah 0,59\% b/b.

Pada penelitian ini dibuat sediaan masker moisturizing yang berbasis emulsi. Sediaan krim masker merupakan salah satu sediaan yang termasuk dalam sediaan emulsi. Emulgator merupakan bahan utama terbentuknya sistem emulsi oleh karena itu pemilihan jenis dan konsentrasi emulgator yang sesuai merupakan pertimbangan utama untuk mendapatkan sistem emulsi yang stabil. Surfaktan anionik (TEA : Stearat) dan nonionik (tween dan span 60) digunakan sebagai emulgator dioptimasikan konsentrasinya 
Evaluasi stabilitas farmasetik dan uji iritasi formula masker sari lemon (Citrus limon L.) dengan yogurt plain

berdasarkan pengamatan pemisahan fase sediaan. Hasil optimasi menunjukkan bahwa formula dengan emulgator surfaktan nonionik mengalami pemisahan fase sedangkan anionik tidak mengalami pemisahan fase. Selanjutnya ekstrak sari lemon diinkorporasi kedalam formula TEAStearat 1:2 sebagai basis formula yang dipilih dengan memvariasikan konsentrasi ekstrak lemonnya $(0,5 ; 1$; 2) $\% \mathrm{~b} / \mathrm{v}$ sehingga menghasilkan formula 1, 2 dan 3 secara berturut-turut. Hal ini dilakukan untuk mengamati tingkat iritasi pada sediaan masker karena kandungan asam yang cukup tinggi dari ekstrak sari lemonnya.

Formula yang dihasilkan dievaluasi karakteristik fisik dan stabilitasnya dengan metode siklus penyimpanan dengan melakukan pengamatan pada parameter uji.

Pada pengamatan karakteristik fisik yang diujikan pada ketiga formula menunjukkan bahwa semua formula memenuhi syarat yang diperbolehkan diantaranya $\mathrm{pH}$ sediaan (tabel 1) masih termasuk kedalam range kulit $\mathrm{pH}$ yang disyaratkan oleh SNI 164954-1998 yaitu 4,5-8, pada uji homogenitas tidak menunjukkan adanya partikel-partikel yang menggumpal atau tidak bercampur, tipe emulsi sedian adalah minyak dalam air, pada pengujian waktu mengering (tabel 2) menunjukkan bahwa semua formula masih berada pada rentang waktu ideal pengaplikasian masker secara umum yaitu 15-20 menit. ${ }^{10}$ Sedangkan daya sebar semua sediaan berbanding lurus dengan berat beban yang diberikan (tabel 3), sedangkan sifat reologi semua formula menunjukkan tipe aliran plastis yang tidak mulai pada titik $(0,0)$ karena adanya nilai yield. Hal ini kemungkinan disebabkan karena adanya padatan berupa zinc oxide pada sediaan sehingga membutuhkan tekanan tertentu untuk mengalir.

Evaluasi stabilitas selanjutnya diujikan untuk semua formula dengan mengamati perubahan parameter uji sebelum dan sesudah uji stabilitas. Parameter yang diujikan diantaranya organoleptik, $\mathrm{pH}$ dan viskositas sediaan.

Hasil pengujian organoleptis sediaan masker menunjukkan tidak ada perubahan sebelum dan sesudah kondisidi paksakan (tabel 4)., hasil yang serupa diperoleh pada pengujian $\mathrm{pH}$ (tabel 1), dan viskositas (tabel 5) berdasarkan hasil analisis statistik anova pada tingkat kepercayaan $95 \%$ dan $99 \%$ menunjukkan tidak terjadi perubahan yang signifikan. Hal ini menunjukkan tidak terjadi reaksi antara 
Evaluasi stabilitas farmasetik dan uji iritasi formula masker sari lemon (Citrus limon L.) dengan yogurt plain

bahan aktif dengan bahan tambahan dalam formula.

Setelah pengujian stabilitas masker selanjutnya dilakukan pengujian iritasi. Uji iritasi dilakukan untuk menentukan potensi iritasi pada kulit setelah diberikan sediaan, sehingga dapat diketahui tingkat keamanan dari sediaan yang dihasilkan. Dari hasil indeks iritasi yang diperoleh dapat disimpulkan formula 1 dan formula 2 tidak mengiritasi, formula 3 memiliki indeks iritasi ringan, pada formula kontrol tanpa ekstrak tidak mengiritasi, pada kombinasi lemon dan yogurt memiliki indeks iritasi sedang.

\section{KESIMPULAN}

Berdasarkan hasil penelitian yang telah dilakukan maka dapat disimpulkan bahwa kombinasi sari lemon (Citrus limon L.) dan yogurt plain dapat diformulasi menggunakan emulgator anionik (TEA-Stearat) $1: 2$ $(1: 2 \% \mathrm{~b} / \mathrm{v})$ menghasilkan sediaan krim masker kestabilan optimal secara farmaseutik, dan sediaan krim masker tidak menimbulkan iritasi dengan konsentrasi lemon 0,5 dan $1 \mathrm{~b} / \mathrm{v} \%$ dalam sediaan.

\section{DAFTAR PUSTAKA}

1. Maregesi SM, Kagashe GA, Felix $F$. Documentation and Phytochemical Screening of Traditional Beauty Products Used in Missenyi District of Tanzania.
Journal of Cosmetics Dermatological Sciences and Applications. 2014;4:360.

2. Atsmanul A. Aktivitas Protease dan Kandungan Asam Laktat pada Yoghurt yang Dimodifikasi Bifidobacterium bifidum dan Diinokulasi Pseudomonas fluorescens (Skripsi). Bogor: Fakultas Matematika dan IImu Pengetahuan Alam. Universitas Institus Pertanian Bogor, 2006.

3. Thanya P. Development of Herbal Facial Mask Cream From Suan Sunandha Palace Facial. International Journal of Advances in Science Engineering and Technology. 2017;5(1):23.

4. Surtiningsih. Cantik dengan Bahan Alami. Jakarta: PT.Alex Media Komputindo, 2005.

5. Rohana. Pengaplikasikan Masker Ekstrak Essensial Oil Mawar Pada Jenis Kulit Kering Untuk Usia Setengah Baya. Jurnal Keluarga Sehat Sejahtera.2014;12:26.

6. Ariyani B. Formulasi Krim Masker Wajah Menggunakan Lapisan Putih Kulit Semangka (Citrullus vulgaris Schard) Sebagai Pelembab. Jurnal Media Farmasi. 2013;11(18):37-38.

7 Faradiba A, Faisal M, Ruhama. Formulasi Krim Wajah Dari Sari Buah Jeruk Lemon (Citrus lemon L.) dan Anggur Merah (Vitisvinifera L.) dengan variasi konsentrasi emulgator. Jurnal farmasi dan farmakologi. 2013;17(1):17-18.

8. Lachman L, Lieberman AH, Kanig L. Teoridan Praktek Farmasi Industri, Edisi 3. Jakarta: Penerbit Universitas Indonesia, 1994. 
Evaluasi stabilitas farmasetik dan uji iritasi formula masker sari lemon (Citrus limon L.) dengan yogurt plain

9. Aisyah F. Uji Iritasi Krim Hasil Fermentasi Bunga Rosella (Hibiscus sabdariffa L.) Dengan Variasi Konsentrasi Emulgator Novemer Pada Kulit Kelinci (Oryctalagus cuniculus). Journal of Pharmaceutical and Medicinal Sciences. 2016;1(2):64.
10. Vieira RP. Physical and Physicochemical Stability Evaluation of Cosmetic Formulations Containing Soybean Extract Fermented by Bifidobacterium animalis. Brazilian Journal of Pharmaceutical Sciences. 200945(3):517. 